\title{
Plant extracts are the potential inhibitors of $\alpha$-amylase: a review
}

\begin{abstract}
Diabetes mellitus is a metabolic disorder characterized by chronic hyperglycemia with disturbances of carbohydrate, lipid and protein metabolism resulting from defects in insulin secretion, insulin action or both. Among the various therapeutic approaches to treat diabetes, postprandial hyperglycemia reduction is at most importance. This approach is used to prevent absorption of glucose by the inhibition of enzymes which hydrolyze carbohydrates, such as alpha-amylase. The $\alpha$-amylase is one of the main products of secretion of the salivary glands and pancreas, which plays a role in the digestion of starch and glycogen and can be found in microorganisms, plants and higher organisms. $\alpha$-amylase enzyme catalyzing the initial step in the hydrolysis of starch to the oligosaccharide mixture consisting of maltose, malt triose 6-8 and oligosaccharides containing glucose units both $\alpha-1,4$ and $\alpha-1,6$ linkages branched. Here in the present work a review was carried to collectively highlight all those potent alpha-amylase inhibitors whose sources are plants. These inhibitors possess antioxidant and are the considered strong tools in future treatments of diabetes mellitus as well free from side effects.
\end{abstract}

Keywords: carbohydrates, diabetes mellitus, hyperglycemia, treatments, hydrolysis, pharmacologically, inhibitors, therapeutic approach, alpha-amylase, medicine
Volume 5 Issue 5 - 2018

\author{
Syed Bilal Shah,' Lubna Sartaj,, Fawad Ali,' \\ Syed Izhar Ali Shah, ${ }^{3}$ Muhammad Tahir Khan ${ }^{4}$ \\ 'State Key Laboratory of Microbial Metabolism, Shanghai jiao \\ Tong University, China \\ 2Department of Biochemistry, Abdul Wali Khan University \\ Mardan, Pakistan \\ ${ }^{3}$ Department of Microbiology and Biotechnology, Abasyn \\ University Peshawar, Pakistan \\ ${ }^{4}$ Department of Bioinformatics, Capital University of Science \\ and Technology, Pakistan
}

\begin{abstract}
Correspondence: Syed Bilal Shah, State Key Laboratory of Microbial Metabolism, and School of Life Sciences and Biotechnology, Shanghai Jiao Tong University, Shanghai 200240, China,Tel +86|3 | 22 |7629|,Email bilalshah@situ.edu.cn
\end{abstract}

Received: September 10,2018 | Published: October 12, 2018

\section{Introduction}

Diabetes mellitus is a group of metabolic diseases considered by hyperglycemia resulting from failures in insulin secretion, insulin function or both. It is characterized by hyperglycemia and accompanied by various chronic vascular complications., ${ }^{1,2}$ An estimated 171 million people worldwide have diabetes, which may probably double in 2030 and about 3.2 million deaths each year are attributable to complications of diabetes; six deaths every minute. ${ }^{3,4}$

Oligosaccharides and disaccharides are decomposed into monosaccharides by Glycosidase and $\alpha$-amylase. Starch is primarily broken down to oligosaccharides owing to the hydrolytic activity of these enzymes. ${ }^{5}$ Like other nutrients, carbohydrates are mostly digested in the small intestine; however, it is the salivary amylase that sets out almost $5 \%$ of the initial breakdown of carbohydrates in the mouth. Due to acidic environment amylase activity is destroyed and hence digestion of carbohydrates is not ensured in the stomach. ${ }^{6}$ Conversely, there is a whole different nature of small intestine where bicarbonates released from the pancreas is basic enough to neutralize the low $\mathrm{pH}$ and optimize the conditions for pancreatic amylase to properly accomplish the breakdown of carbohydrates into oligosaccharides. ${ }^{7}$ The glucosidase enzymes (maltase, lactase and sucrase) secreted by intestinal mucosa complete the breakdown of oligosaccharides into monosaccharide units which are only then absorbed by the body and transported to the liver through the portal vein. Body utilizes these monosaccharides as one of the most direct sources of energy for various life process while those unused are immediately stored in the liver as glycogen or in the form of fat (triglycerides) in adipose tissue, plasma and liver. ${ }^{8}$ Those carbohydrates which are indigestible in the small intestine are subjected to bacterial fermentation in the colon to produce methane, carbon dioxide and short chain fatty acids. Salivary $\alpha$-amylase, because of its substantial utility in the oral cavity, has been exploited as a target for designing structural based compounds that could preclude the formation of plaque and further succession of dental caries. Ethno pharmacologically tackled bioassay directed isolation and have granted an advantage in the identification of possible inhibitors of $\alpha$-amylase from plant resources. ${ }^{9}$ The procedure of finding concentrations of $\alpha$-amylase inhibitor depends on the extent of $\alpha$-amylase activity resulting from iodine staining power in the presence/absence of an inhibitor for the enzyme action on soluble starch or using an alkaline reactive brown whose reduction products are determined photo metrically as reported by Bernfeld..$^{10,11}$ This review emphasizes on $\alpha$-amylase inhibitory activity of those plants and derived compounds so far recently reported.

\section{Potent inhibitors of $\alpha$-amylase from different plants extracts}

Herbivorous insects use a plug of extracellular enzymes to digest their food. One of these is $\alpha$-amylase, which binds to 1,4 glycoside and slash in starch, glycogen, oligosaccharides and polysaccharides. Several functional proteins such as lectin, knottin-like, cereal type, Kunitz, c-purothionin-like, and thaumatin, which is often found in the seeds of legumes and graminaceous plants, has been reported to inhibit $\alpha$-amylase of the insect midgut, thus blocking the main source of energy for growth and development of insects. ${ }^{12}$ Joining these ICA and amylase protein forms a stable enzyme-inhibitor complex. This leads to excessive larvae digestive glands secrete digestive enzymes and answers larvae cause sanorexia, hypogenesis, and even death. ${ }^{12,13}$ AAIS protein are major, however, are non-competitive inhibitors of the insect midgut and $\alpha$-amylase have their own particular kinetic properties regarding inhibitory activity, $\mathrm{pH}$ optimum, thermal stability, and optimal incubation time. Further practical application of natural biogenic protein ICA still needs more research before may be used as tools for insect pest control.

Several authors have reviewed the possibility of medicinal plants as inhibitors of $\alpha$-amylase. It has been reported that around 800 different plant species exhibit anti-diabetic properties relevant to the 
treatment of type 2diabetes. A wide range of principles derived from plants belonging to the compounds, mainly glycosides, alkaloids, hypoglycans, galactomannan gum, polysaccharides, steroids, peptidoglycan, guanidine, glycol peptides and terpenoids, have shown biological activity against hyperglycemia. ${ }^{14} \mathrm{~A}$ list of plants reported to have significant inhibitory activity against $\alpha$-amylase enzyme is shown in (Table 1). L. Syzygium cumini L. (syn: Eugenia jambolana Lam) and Psidium guajava L. are extensively used traditional system of medicine for the treatment of diabetes in India. Aqueous extracts of seeds and P.S. cuminigua java leaves both demonstrate dose-dependent inhibitory effect on $\alpha$-amylase activity. ${ }^{15}$ Extract of $S$. cumini seeds also drastically diminish blood glucose point in diabetic rats. ${ }^{14,16}$ It was confirmed that the extracts of ethyl acetate, methanol, and hexane from two varieties of Amaranthus caudatus L. Seeds (White and Red Victor Oscar. Oil) showed inhibitory activity of $\alpha$-amylase (above 80 $\%$ inhibition rate) by $0.251 \mathrm{mg} / \mathrm{mL}$. Extracts buffered various plant species namely Desert date L., Camellia sinensis L. Del., Galega officinalis L., Holarrhena floribunda (Don) Durand and Schinz, Khaya senegalensis (Desr.) A. Juss., Melissa officinalis L., Mitragyna inermis (Willd) O. Ktze., Rosmarinus officinalis L., Securidaca long epedunculata Fresen., Tamarindus indica L., Taraxacum officinale web. Wiggex., Vaccinium myrtillus L. and were selected for $\alpha$-amylase activity and showed momentous inhibitory activity (above $45 \%$ inhibition rate of $0.2 \mathrm{~g} / \mathrm{ml}$ ). ${ }^{17}$ The methanol extracts of 41 plants used in traditional medicine in Mongolia have been tested for $\alpha$-amylase inhibitory properties and significant inhibition of the enzyme was demonstrated by Rhodiola rosea L., Ribesand vacciniumulig in osumpullchelum Turcz L; geranium extracts pretense L, Leontopodium ochroleucum Beauv., Paeonia anomala L., and Penta phylloides fruticosa L. Schwarz illustrate $\alpha$-amylase inhibitory activity greater than $30 \% .{ }^{18}$ Loizzo, et al. ${ }^{19}$ examined extracts of methanol, hexane and chloroform from nine Lebanon recommended for diabetes traditional medicinal plants. ${ }^{19}$ Ayurveda, the traditional system of herbal medicine practiced in India for over thousands of years have reports of anti-diabetic plants with no known side effects apparent. ${ }^{20,21}$ Chloroform extracts six plants Azadirach taindica A. Linumusita tissimum L., Jussnamely, S. cumini, Tenuflorum ocimum L., Curry tree (L.) Spreng and traditionally used din Ayurveda with Bougain villea spectabilis Willd, used as a plant of hypoglycemia in the West Indies and Asia were selected for inhibitory activity of $\alpha$-amylase Significant inhibition with extracts from O. tenuflorum..$^{20}$ Six more Indian medicinal plants were tested for their effect on $\alpha$-amylase activity between them, Mangifera indica L., Embelia ribes Burm., Phyllanthus mader as patensis Linn. Punica granatum L. and showed interesting inhibitory activity of $\alpha$-amylase. ${ }^{22}$ The enzyme $\alpha$-amylase inhibitor $(\alpha-\mathrm{AI})$, which inhibits the animal saliva and pancreatic $\alpha$-amylase, has been identified and isolated from various species of plants. ${ }^{23}$ Among these plants, seeds of Phaseolus vulgaris L. containing protein inhibitor sand $\alpha$-amylase inhibitor- 1 iso-form $\alpha$-AI have been isolated and characterized. A $\alpha$-AI common bean-1 has been reported to have relatively great potential as an anti-obesity and anti-diabetes remedy extensive. ${ }^{23}$

Table I Plants with $\alpha$-amylase inhibitory activity

\begin{tabular}{|c|c|c|c|c|c|}
\hline Plant & Part used & $\begin{array}{l}\text { Type of } \\
\text { extract }\end{array}$ & $\begin{array}{l}\text { Activity (\% } \\
\text { inhibition) } \\
\text { (concentration) } \\
\text { (mg/ml) }\end{array}$ & Control & References \\
\hline $\begin{array}{l}\text { Acanthaceae Andrographis } \\
\text { paniculate Nees }\end{array}$ & $\begin{array}{l}\text { Leaf and } \\
\text { aerial parts }\end{array}$ & Ethanol & $52.5(50.9) 54.8(I I .3)$ & $\begin{array}{l}\text { Acarbose with } 50.1 \% \text { of maxim inhibition } \\
\text { at } 10 \mathrm{mg} / \mathrm{mL}\end{array}$ & 24 \\
\hline Actinidiaceae Actinidia deliciosa & Leaf & $\begin{array}{l}\text { Methanol } \\
90 \%\end{array}$ & $50(0.0429)$ & $\begin{array}{l}\text { Voglibose with } 50 \% \text { of inhibition at } \\
0.0466 \mathrm{mg} / \mathrm{mL}\end{array}$ & 25 \\
\hline $\begin{array}{l}\text { Balanitaceae Balanitesa egyptiaca } \\
\text { L }\end{array}$ & Bark & $\begin{array}{l}\text { Aqueous } \\
\text { buffered }\end{array}$ & $45-75(200)$ & $\begin{array}{l}\text { Acarbose inhibition higher than } 75 \% \text { at } \\
200 \mathrm{mg} / \mathrm{mL}\end{array}$ & 17 \\
\hline Coniferae Ginkgo biloba L & Leaf & Ethanol & $70(50)$ & Non-treated enzyme & 26 \\
\hline Ericaceae Vaccinium myrtillus L. & Leaf & $\begin{array}{l}\text { Aqueous } \\
\text { buffered }\end{array}$ & $>75(200)$ & $\begin{array}{l}\text { Acarbose, inhibition higher than } 75 \% \text { at } \\
200 \mathrm{mg} / \mathrm{mL}\end{array}$ & 17 \\
\hline Geraniaceae Geranium pratense L. & Aerial part & Methanol & $43.9(0.3 \mathrm{mg} / \mathrm{mL})$ & $\begin{array}{l}\text { Acarbose with } 79.6 \% \text { of inhibition at } \\
0.1 \mathrm{mg} / \mathrm{mL}\end{array}$ & 18 \\
\hline Fabaceae Cajanus cajan L. & Seed & $\begin{array}{l}\text { Aqueous } \\
\text { buffered }\end{array}$ & $100(2 \mathrm{mg}$ protein) & Non-treated enzyme & 27 \\
\hline $\begin{array}{l}\text { Malvaceae Hibiscus sabdariffa } \\
\text { Linn. }\end{array}$ & Flower & $\begin{array}{l}\text { Methanol } \\
50 \%\end{array}$ & $100(10 \mathrm{~mL} / \mathrm{g}$ fr. wt. $)$ & Non-treated enzyme & 28 \\
\hline Myrsinaceae Embelia ribes Burm.f. & Seed & Ethanol & 59.3 & $\begin{array}{l}\text { Phaseolus vulgaris with } 59.4 \% \text { of inhibition } \\
\text { at } 0.0125 \mathrm{mg} / \mathrm{mL}\end{array}$ & 22 \\
\hline Paeoniaceae Paeonia anomala L. & Root & Methanol & $33.1(0.3 \mathrm{mg} / \mathrm{mL})$ & $\begin{array}{l}\text { Acarbose with } 79.6 \% \text { of inhibition at } \\
0.1 \mathrm{mg} / \mathrm{mL}\end{array}$ & 18 \\
\hline Pinaceae Cedrus libani A. Rich & $\begin{array}{l}\text { Essential oils } \\
\text { from cones }\end{array}$ & $\begin{array}{l}\text { Aqueous } \\
\text { buffered }\end{array}$ & $3 I(I)$ & $\begin{array}{l}\text { Acarbose with } 50 \% \text { of at inhibition } \\
1.22 \mathrm{mg} / \mathrm{mL}\end{array}$ & 19 \\
\hline $\begin{array}{l}\text { Polygalaceae Securidaca } \\
\text { longepidunculata Fresen }\end{array}$ & Root & $\begin{array}{l}\text { Aqueous } \\
\text { buffered }\end{array}$ & $20-45(200 \mathrm{mg} / \mathrm{mL})$ & $\begin{array}{l}\text { Acarbose with inhibition higher than } 75 \% \\
\text { at } 200 \mathrm{mg} / \mathrm{mL}\end{array}$ & 17 \\
\hline Punicaceae Punica granatum L. & Fruit rind & Ethanol & $68.2(1)$ & $\begin{array}{l}\text { Phaseolus vulgaris with } 59.4 \% \text { of inhibition } \\
\text { at } 0.0125 \mathrm{mg} / \mathrm{mL}\end{array}$ & 22 \\
\hline $\begin{array}{l}\text { Rosaceae Pentaphylloides fruticosa } \\
\text { (L.) }\end{array}$ & $\begin{array}{l}\text { Leaf and } \\
\text { branch }\end{array}$ & Methanol & $31.2(0.3 \mathrm{mg} / \mathrm{mL})$ & $\begin{array}{l}\text { Acarbose with } 79.6 \% \text { of inhibition at } \\
0.1 \mathrm{mg} / \mathrm{mL}\end{array}$ & 18 \\
\hline $\begin{array}{l}\text { Rubiaceae Mitragyna inermis } \\
\text { (Wild) }\end{array}$ & Leaf & $\begin{array}{l}\text { Aqueous } \\
\text { buffered }\end{array}$ & 75 & $\begin{array}{l}\text { Acarbose with inhibition higher than } 75 \% \\
\text { at } 200 \mathrm{mg} / \mathrm{mL}\end{array}$ & 17 \\
\hline Rutaceae Murraya koenigii L. & Leaf & Chloroform & 56.64 & $\begin{array}{l}\text { Acarbose with } 50 \% \text { of at inhibition } \\
1.22 \mathrm{mg} / \mathrm{mL}\end{array}$ & 20 \\
\hline $\begin{array}{l}\text { Saxifragaceae Bergenia ciliata, } \\
\text { Haw. }\end{array}$ & Rhizome & $\begin{array}{l}\text { Methanol } \\
50 \%\end{array}$ & $93.5(150)$ & Non-treated enzyme & 29 \\
\hline Theaceae Camellia sinensis L. & Leaf & $\begin{array}{l}\text { Aqueous } \\
\text { buffered }\end{array}$ & $45-75(200)$ & $\begin{array}{l}\text { Acarbose with inhibition higher than } 75 \% \\
\text { at } 200 \mathrm{mg} / \mathrm{mL}\end{array}$ & 17 \\
\hline
\end{tabular}


Diabetes was multi factorial in origin and therapeutic approach to treat diabetes was to delay glucose absorption through the inhibition of enzymes $\alpha$-amylase. Brown extracts of rice was also evaluated for its $\alpha$-amylase inhibitory potential. Inhibitors $\alpha$-amylase digestion and absorption of carbohydrates glucose lag, and therefore could be beneficial against the onset of type 2 diabetes. ${ }^{24}$

The inhibitory activity of $\alpha$-amylase shown in Figure 1 . As the results, in free phenolic compounds, extracts of red rice have the highest inhibition activity $(78.56 \%)$, while extracts from black rice have lower activity inhibition (53.63\%) and inhibition activity of extracts of black rice was (68.16\%). Similarly, in consolidated form, inhibition activity was greater in extracts of red rice $(48.67 \%)$ and lowest in extracts of white rice $(30.60 \%)$. Free forms of phenolic compounds always have the highest inhibiting activity of phenolic compounds bound form three types of rice.

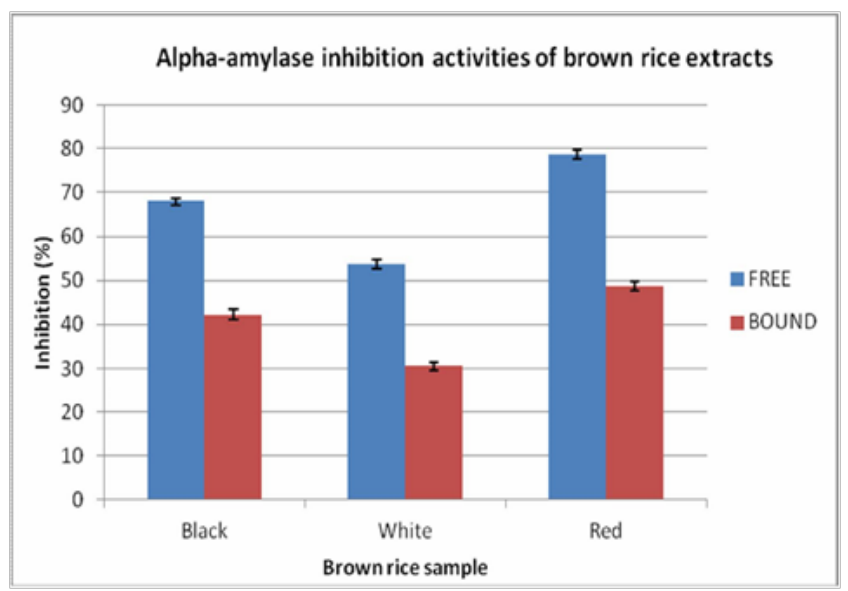

Figure I Alpha-amylase \% inhibition activities in various types of rice.

Inhibition activities of $\alpha$-amylase free and bound phenolics. In some previous studies, the presence of $\alpha$-amylase inhibitors have also been reported in grains, ${ }^{25}$ wheat, ${ }^{21}$ Linumusita tissimum L., sorghum, ${ }^{23}$ maize (Blanco-Labra and, ${ }^{21}$ peanuts, ${ }^{19}$ Linumusita tissimum L., and calluses ${ }^{26}$ In the present study, we detected a high percentage of inhibition in extracts of red rice $(78.56 \%)$. These results indicate that phenol compounds in rice mainly existed in the free form rather than in bound form. There is a positive relationship between total phenolic content, antioxidant capacity and inhibition activity of $\alpha$-amylase. It also confirms that the red brown rice not only consumed as functional foods, but also use as pharmaceutical drugs. As the mechanism and metabolism of brown rice extract involved in this inhibitory activity corresponding to type 2 diabetes $\alpha$ - amylase effect is unclear and work.

On bioavailability of phenolic compounds has been limited, it is vital to do more research on the metabolic pathway and functional mechanism of extract of brown rice on type 2 diabetes. ${ }^{27}$

Alpha amylase enzyme plays an important role in start breakdown complex carbohydrate into simple molecules. Intonation of $\alpha$-amylase activity using affects carbohydrates as an energy source and this intonation stronger. Most significantly is decomposition of complex carbohydrates. Most studies have focused on phenolic compounds amylase antibodies. The proposed inhibitory capacity of flavonoids action mechanism correlates inhibition potency of these compounds with the number of hydroxyl groups in the B ring of the flavonoid skeleton with the formation of hydrogen bounds between the hydroxyl groups of the ligands polyphenol and the catalytic residues of the binding site of the enzyme. The high inhibitory capacity observed in flavonols and in their groups. It is ${ }^{28}$ suggested that the interaction between tannins, quinic acid as galloylated, $\alpha$-amylase and human also correlates with free $\mathrm{OH}$ groups in the tannin, which are capable of participating in hydrogen bonding. However, in this review may notice that the tannins are not always an effective inhibitor of $\alpha$-amylase. This compound showed $100 \%$ inhibition in 24 hours and 50\% inhibition at same next time. The similar process was conducted to estimate this activity in both studies. ${ }^{29}$ However, the extract concentration and incubation time for tested enzyme were different for both. ${ }^{30}$ The study showed distinction in the concentration of the test compound and incubation time of the enzyme, ${ }^{16}$ the changes showed in the result clearly. Inhibitions of $85 \%$ and $50 \%$ rosmarinic acid and $23 \%$ and $55 \%$ for daidzein in tests using starch and nitrophenyl-maltopentao side $\rho$ - $\alpha$-D-(PNPG) as substrate respectively. ${ }^{31}$ Comparing study of $\alpha$-amylase inhibitory activity observe significant difference in the percentage inhibition for the same compound. This is due to a number of valuable test methods available for amylase activity. ${ }^{32}$

\section{Conclusions and future developments}

Alpha-amylase, salivary or pancreatic enzyme plays an important role in early break down complex carbohydrate into simple molecules. Modulation of $\alpha$-amylase activity using affects carbohydrates as an energy source and this modulation is stronger. Most significantly is decomposition of complex carbohydrates. Therefore, some changes in the trials reported by investigators could express different results for the inhibitory activity of $\alpha$-amylase. As the intake of phenolic compounds is associated with many beneficial effects, it is also necessary to consider the dosage for humans, because it is possible to reduce the activity of $\alpha$-amylase by eating food or rich medicinal herbs in polyphenols with strong activity $\alpha$-amylase, if one takes into consideration that this source of polyphenols have different types of these compounds in varying concentration. Therefore, the available evidence is most needed about the safety of using $\alpha$-amylase inhibitors natural. From the above study it is concluded that, there is a need for new agents, therapeutic strategies or design of functional foods that could act in the physiological regulation of the absorption of sugar, sugar levels in the blood and prevention of oral diseases. For the future a standardized protocol for potential inhibitors perhaps should be developed in order to minimize the differences between the results obtained. Considering the above discussed literature and potent antidiabetic potentialities, ethno-medicinal plants may play a very important role in the modern system of medicine and these efforts may provide treatment to everyone and focus on the role of traditional novel medicine plants that have anti-diabetic abilities.

\section{Funding}

The author received no financial support for the review, authorship, and/or publication of this review article.

\section{Acknowledgements}

None.

\section{Conflict of interest}

The author declares there is no conflicts of interest in this work. 


\section{References}

1. Feng J, Yang XW, Wang RF. Bio-assay guided isolation and identification of $\alpha$ - glucosidase inhibitors from the leaves of Aquilaria sineensis. Phytochemistry. 2011;72:242-247.

2. Nickavr B, Mosazadeh G. Influence of Three Morus Species Extracts on?-Amylase Activity. Iranian Journal of Pharmaceutical Research. 2009;8(2):115-119.

3. Sancheti S, Sancheti, Sandesh, et al. Chaenomeles sinensis: A poten $\alpha$-and $\beta$-glucosidase inhibitor. American Journal of Pharmacology and Toxicology. 2009;4(1):8-11.

4. Deutschlander M, Vande VM, Roux S, et al. Hypoglycaemic activity of four plant extracts traditionally used in South Africa for diabetes. $J$ Ethnopharmacol. 2009;124(3):619-624.

5. Ranilla LG, Kwon YI, Apostolidis E. Phenolic compounds, antioxidant activity and in vitro inhibitory potential against key enzymes relevant for hyperglycemia and hypertension of commonly used medicinal plants, herbs and spices in Latin America. Bioresour Technol. 2010;101:46764689 .

6. Ali H, Houghton PJ, Soumyanath A. Soumyanath, $\alpha$-Amylase inhibitory activity of some Malaysian plants used to treat diabetes; with particular reference to Phyllanthus amarus. J Ethnopharmacol. 2006;107(3):449455 .

7. Bhandari MR. $\alpha$-Glucosidase and $\alpha$-amylase inhibitory activities of Nepalese medicinal herb Pakhanbhed (Bergenia ciliata, Haw). Food Chemistry. 2008;106(1):247-252.

8. Kim YM, Wang MH, Rhee HI. A novel $\alpha$-glucosidase inhibitor from pine bark. Carbohydr Res. 2004;339:715-717.

9. Kim YM, Jeong YK, Wang MH, et al. Inhibitory effect of pine extract on $\alpha$-glucosidase activity and postprandial hyperglycemia. Nutrition. 2005;21(6):756-761.

10. Bilal M, Iqbal MS, Shah SB, et al. Diabetic complications and insight into antidiabetic potentialities of ethno-medicinal plants: a review. Recent Pat Inflamm Allergy Drug Discov. 2018;12(1):7-23.

11. Mosca $\mathrm{M}$, Boniglia $\mathrm{C}$, Carratù $\mathrm{B}$, et al. Determination of $\alpha$-amylase inhibitor activity of phaseolamin from kidney bean (Phaseolus vulgaris) in dietary supplements by HPAEC-PAD. Anal Chim Act. 2008;617:192-195.

12. Franco OL, Rigden DJ, Melo FR. Plant alpha-amylase inhibitors and their interaction with insect alpha-amylases. Eur J Biochem. 2002;269(2):397412 .

13. Xuan-wei Z. Study progress on bioactive proteins from Ganoderma spp Natural Product Research \& Development. 2007;19:465-467.

14. Mentreddy SR. Medicinal plant species with potential antidiabetic properties. Journal of the Science of Food and Agriculture. 2007;87:743750 .

15. Karthic K, Kirthiram KS, Sadasivam S. Identification of $\alpha$-amylase inhibitors from Syzygium cumini Linn seeds. Indian J Exp Biol. 2008;46(9):677-680

16. Kumar A, Ilavarasan R, Jayachandran T, et al. Anti-diabetic activity of Syzygium cumini and its isolated compound against streptozotocininduced diabetic rats. Journal of Medicinal Plants Research. 2008;2(9):246-249.
17. Funke I, Melzig M. Traditionally used plants in diabetes therapy: phytotherapeutics as inhibitors of alpha-amylase activity. Rev bras Pharmacogn. 2006;16(1):1-5.

18. Kobayashi K, Baba E, Fushiya S, et al. Screening of mongolian plants for influence on amylase activity in mouse plasma and gastrointestinal tube. Biol Pharm Bull. 2003;26(7):1045-1048.

19. Loizzo MR, Saab AM, Tundis R, et al. In vitro inhibitory activities of plants used in Lebanon traditional medicine against Angiotensin Converting Enzyme (ACE) and digestive enzymes related to diabetes. $J$ Ethnopharmacol. 2008;119(1):109-116.

20. Bhat M, Zinjarde SS, Bhargava SY. Antidiabetic Indian plants: a good source of potent amylase inhibitors. Evid Based Complement Alternat Med. 2011.

21. Shah SB, Shah SIA, Sartaj L, et al. Effect of Nigella sativa seeds extracts on clinically important bacterial and fungal species. MOJ Bioequiv Availab. 2018;5(4):218-221.

22. Prashanth D, Padmaja R, Samiulla D. Effect of certain plant extracts on $\alpha$-amylase activity. Fitoterapia. 2001;72(2):179-181.

23. Wang HH, Chen CL, Jeng TL. Comparisons of $\alpha$-amylase inhibitors from seeds of common bean mutants extracted through three phase partitioning. Food Chemistry. 2011;128(4):1066-1071.

24. Subramanian R, Asmawi MZ, Sadikun A. In vitro alpha-glucosidase and alpha-amylase enzyme inhibitory effects of Andrographis paniculata extract and andrographolide. Acta Biochim Pol. 2008;55(2):391-398.

25. Shirosaki MT, Koyama, Yazawa K. Anti-hyperglycemic activity of kiwifruit leaf (Actinidia deliciosa) in mice. Biosci Biotechnol Biochem. 2008;72(4):1099-1102.

26. Pinto Mda S, Kwon YI, Apostolidis E, et al. Potential of Ginkgo biloba L. leaves in the management of hyperglycemia and hypertension using in vitro models. Bioresour Technol. 2009;100(24):6599-6609.

27. Shah SB, Parveen Z, Bilal M, et al. Assessment of antimicrobial, antioxidant and cytotoxicity properties of Camellia sinensis L. Pak J Pharm Sci. 2018;31(4):1285-1291.

28. Kandra L, Gyémánt G, Zajacz A. Inhibitory effects of tannin on human salivary $\alpha$-amylase. Biochemical and biophysical research communications. Biochem Biophys Res Commun. 2004;319(4):12651271.

29. Ryu B. Exhibitory effects of compounds from brown alga Ecklonia cava on the human osteoblasts. Journal of Biotechnology. 2008;136:588.

30. Hansawasdi C, Kawabata J, Kasai T. $\alpha$-Amylase inhibitors from roselle (Hibiscus sabdariffa Linn.) tea. Biosci Biotechnol Biochem. 2000;64(5):1041-1043.

31. Zaman S, Shah SB, Jiang TY. Saline conditions alter morpho-physiological intensification in purslane (Portulaca oleracea L). J Biol Regul Homeost Agents. 2018;32(3):635-639.

32. Ragunath C, Manuel SGA, Kasinathan C. Structure of human salivaryamylase at 1.6 A resolution: implications for its role in the oral cavity. Acta Crystallogr D Biol Crystallogr. 1996;52:435-446. 